Research article

\title{
Blood and alveolar lymphocyte subsets in pulmonary cytomegalovirus infection after lung transplantation François Stéphan ${ }^{* 1}$, Jean-François Bernaudin ${ }^{1}$, Danielle Cesari ${ }^{1}$, Anne Fajac ${ }^{1}$, Dominique Grenet MD², Isabelle Caubarrere ${ }^{2}$ and Marc Stern ${ }^{2}$
}

Address: ${ }^{1}$ Laboratoire d'Histologie-Biologie Tumorale, AP-HP Hôpital Tenon, 4 rue de la Chine 75020 Paris, France and ${ }^{2}$ Service de Pneumologie, Hôpital Foch, 40 rue Worth, BP 36, 92151 Suresnes, France

E-mail: François Stéphan* - francois.stephan@hcuge.ch; Jean-François Bernaudin - jean-francois.bernaudin@tnn.ap-hop-paris.fr; Danielle Cesari - jean-francois.bernaudin@tnn.ap-hop-paris.fr; Anne Fajac - jean-francois.bernaudin@tnn.ap-hop-paris.fr;

Dominique Grenet - jean-francois.bernaudin@tnn.ap-hop-paris.fr; Isabelle Caubarrere - jean-francois.bernaudin@tnn.ap-hop-paris.fr; Marc Stern - jean-francois.bernaudin@tnn.ap-hop-paris.fr

${ }^{*}$ Corresponding author

Published: 17 September 200I

BMC Infectious Diseases 200I, I:15

This article is available from: http://www.biomedcentral.com//47I-2334/I/I5

(c) 200I Stéphan et al; licensee BioMed Central Ltd. Verbatim copying and redistribution of this article are permitted in any medium for any non-commercial purpose, provided this notice is preserved along with the article's original URL. For commercial use, contact info@biomedcentral.com

Keywords: Lung Transplantation, Cytomegalovirus, Lymphocytes, Bronchoalveolar lavage, Flow cytometry

\begin{abstract}
Background: Cytomegalovirus (CMV) pneumonitis has been shown to be associated with lymphocytic alveolitis after lung transplantation. In the present study, we investigated a series of bronchoalveolar (BAL) and blood samples, collected in the absence of rejection or acute infectious episodes. in order -I: to evaluate intra-alveolar cell population changes concomitant with CMV replication and -2: to reappraise the value of cell population analysis in the management of patients after lung transplantation.
\end{abstract}

Methods: We used flow cytometry to investigate modifications of lymphocyte subpopulations related to pulmonary cytomegalovirus infections in blood and BAL samples from a series of 13 lung transplant recipients. After exclusion of samples obtained during pulmonary rejection, bronchiolitis obliterans or acute bacterial infection, 48 blood and BAL samples were retained for analysis: 17 were CMV positive by shell-vial assay and 3 I were CMV negative in blood and BAL.

Results: Our results demonstrate that pulmonary CMV infection is associated with a significant increase in the total lymphocyte population in BAL samples, but with minor modifications of the various lymphocyte subpopulations and a significantly higher absolute number of $B$ lymphocytes in blood samples.

Conclusions: Cytomegalovirus pulmonary infection is accompanied by only minor changes in BAL lymphocyte subpopulations. The study of BAL lymphocyte subpopulations therefore appears to be of limited clinical value in the diagnosis of pulmonary CMV infection. However, increased blood Blymphocytes seems to be a clinical feature associated with CMV infection. 


\section{Background}

Cytomegalovirus (CMV) infections are the most frequent viral infections in lung transplant recipients [1]. Studies in man and the murine model of CMV have demonstrated that development of pathological effects is not exclusively related to viral replication in the lung, and a host immune response is required for induction of pneumonitis $[2,3]$. For instance, CMV pneumonitis has been shown to be associated with lymphocytic alveolitis after bone marrow transplantation [4] or lung transplantation [5]. In murine models of CMV pneumonitis, increased numbers of both CD4+ T helper and CD8+ suppressor/ cytotoxic pulmonary lymphocytes have been observed [6]. Moreover, in non-HIV immunodepressed patients, it has been shown that CD8+ T lymphocytes play a particularly important role in host defense against cytomegalovirus infection [7-9] and cytotoxic CD8+ T lymphocytes are activated in situ during CMV pneumonia [10]. However, after lung transplantation, the cellular alveolar modifications related to CMV replication have not been clearly characterized, particularly compared to those associated with rejection [11-13]. Bronchoalveolar lavage (BAL) has been largely developed in the management of lung transplant recipients and in the investigation of alveolar cells, particularly in order to detect an opportunistic infection, such as CMV pneumonitis [1]. All patients transplanted in our institution are routinely evaluated by BAL for detection of opportunistic infection and routine analysis of the various subsets of intra-alveolar cells, particularly lymphocytes. In the present study, we investigated a series of BAL and blood samples collected in the absence of rejection or acute infectious episodes, in order -1: to evaluate intra-alveolar cell population changes concomitant with CMV replication and -2: to reappraise the value of cell population analysis in the management of patients after lung transplantation.

\section{Methods}

\section{Patients and specimen collection}

The lung transplantation protocol was approved by the institutional review board for human studies and informed consent was obtained from the subjects after detailed description of the procedure. According to French legislation, this study did not need Comité Consultatif de Protection des Personnes dans la Recherche Biomédicale (C.C.P.P.R.B.) approval.

Thirteen lung transplant recipients ( 4 females, 9 males) were studied, with a mean follow-up of 15 months (range: 1 to 42 months). The median age of the patients was 27 years (range: $18-56$ ). The patient characteristics are reported in Table 1 . The immunosuppressive regimen consisted of cyclosporin (whole blood level between 200 to 300 ?g/L), azathioprine $(1.5-2 \mathrm{mg} / \mathrm{kg} / \mathrm{d})$, and steroids (started at $\mathrm{d}+5$ at $0.2-0.3 \mathrm{mg} / \mathrm{kg} / \mathrm{d}$, up to $1 \mathrm{mg} /$ $\mathrm{kg} / \mathrm{d}$ at $\mathrm{d}+21$ until the third month; doses were then tapered to $0.2 \mathrm{mg} / \mathrm{kg}$ at 6 months) with the additional perioperative infusion of antilymphocyte globulins (Thymoglobulines Mérieux $2.5 \mathrm{mg} / \mathrm{kg} / \mathrm{d}$ for 5 days). Acute rejection was treated with IV pulses of methylprednisolone $(15 \mathrm{mg} / \mathrm{kg} / \mathrm{d}$ ) for 3 consecutive days. Every episode of CMV infection was treated by intravenous ganciclovir, $5 \mathrm{mg} / \mathrm{kg}$ every $12 \mathrm{~h}$ for 14 days. Maintenance therapy $(5 \mathrm{mg} / \mathrm{kg} / \mathrm{d})$ was initially provided for patients suffering from recurrent CMV infection.

Routine bronchoscopy with BAL and transbronchial biopsy (TBB) were performed at regular intervals after transplantation (monthly during the first 6 months, every 3 months until the end of the first year, then twice a year) to monitor for infection and rejection, and when clinically indicated. Peripheral blood samples were collected at the time of each bronchoscopy and at the attending physician's discretion. BAL fluids were analyzed for evidence of infection, differential cell counts, and lymphocyte marker studies, when possible. Peripheral blood lymphocyte markers were analyzed simultaneously.

Nine of the 13 patients studied developed a total of 36 CMV infections in blood or BAL or both. Four patients never developed CMV infections.

One hundred and twenty-two blood samples (median: 8 per patient, range: 1-17 per patient) and 107 BAL samples (median: 7 per patient, range: $1-17$ per patient) were collected over the study period for CMV culture. Fifty nine BAL samples were excluded for the studyowing to the presence of concomitant pulmonary rejection $(\mathrm{n}=$ 36), bronchiolitis obliterans $(\mathrm{n}=11)$, bacterial pnumonia $(n=1)$, other viral infection ( $n=1)$, or insufficient recovery rate of cells from BAL to allow differential cell counts and lymphocytes marker studies $(n=10)$. Forty-eight blood and BAL samples from 12 of the 13 patients were analyzed, as the 13th patient, who always suffered from concomitant pulmonary rejection, was excluded from the study.

\section{Viral cultures}

Rapid CMV culture by the shell vial technique was used for BAL fluid and blood, as previously described [14].

\section{Definition of CMV infection}

CMV infection was defined as the detection of CMV in blood or BAL fluid by culture [15]. CMV pneumonitis was defined as CMV infection and the presence of characteristic cytomegalic inclusion-bearing cells on cytologic examination of BAL specimens or histopathologic examination of transbronchial biopsy specimens [15]. 
Table I: Characteristics of lung transplant recipients entering the present study

\begin{tabular}{|c|c|c|c|c|c|c|c|c|c|c|}
\hline \multirow[t]{2}{*}{ Patient } & \multirow[t]{2}{*}{$\begin{array}{l}\text { Age } \\
\text { (yr) }\end{array}$} & \multirow[t]{2}{*}{ Sex } & \multirow[t]{2}{*}{ Disease } & \multicolumn{2}{|c|}{$\begin{array}{l}\text { CMV } \\
\text { status* }\end{array}$} & \multirow{2}{*}{$\begin{array}{c}\text { CMV } \\
\text { infection } \\
\text { episodes } \\
\dagger(n)\end{array}$} & \multicolumn{2}{|c|}{$\begin{array}{l}\text { Samples } \\
\text { studied }\end{array}$} & \multirow[t]{2}{*}{$\begin{array}{l}\text { Follow-up } \\
\text { (mo) }\end{array}$} & \multirow{2}{*}{$\begin{array}{c}\text { Steroid } \\
\text { dose } \\
(\mathrm{mg} / \mathrm{kg}) \\
*_{*}\end{array}$} \\
\hline & & & & $\mathrm{D}$ & $\mathrm{R}$ & & $\begin{array}{l}\text { BAL } \\
\text { CMV } \\
+(n)\end{array}$ & $\begin{array}{l}\text { BAL } \\
\text { CMV } \\
-(n)\end{array}$ & & \\
\hline 1 & 25 & M & $\begin{array}{l}\text { Idiopathic pulmonary } \\
\text { fibrosis }\end{array}$ & + & + & 1 & 1 & 0 & 1 & $0.7(-)$ \\
\hline 2 & 53 & $M$ & $\begin{array}{c}\text { Paracicatricial } \\
\text { emphysema }\end{array}$ & + & + & 2 & 1 & 2 & 17 & $\begin{array}{c}0.2 \\
(0.2-0.5)\end{array}$ \\
\hline 3 & 56 & $\mathrm{~F}$ & Lymphangiomyomatosis & + & + & 8 & $4 \ddagger$ & 6 & 19 & $\begin{array}{c}0.35 \\
(0.2-15)\end{array}$ \\
\hline 4 & 18 & $\mathrm{~F}$ & Cystic fibrosis & + & - & 5 & 2 & 2 & 11 & $\begin{array}{c}0.2 \\
(0.2-0.9)\end{array}$ \\
\hline 5 & 48 & $M$ & $\begin{array}{l}\text { Idiopathic pulmonary } \\
\text { fibrosis }\end{array}$ & - & + & 4 & 2 & 2 & 5 & $\begin{array}{c}0.9 \\
(0.3-15)\end{array}$ \\
\hline 6 & 20 & M & Cystic fibrosis & - & + & 4 & 2 & 1 & 5 & $\begin{array}{c}0.8 \\
(0.8-1)\end{array}$ \\
\hline 7 & 42 & M & Panlobular emphysema & - & + & 4 & 2 & 2 & 15 & $\begin{array}{c}0.25 \\
(0.2-0.9)\end{array}$ \\
\hline 8 & 37 & $\mathrm{~F}$ & $\begin{array}{l}\text { Primary pulmonary } \\
\text { hypertension }\end{array}$ & - & + & 6 & 3 & 2 & 16 & $\begin{array}{c}0.2 \\
(0.2-15)\end{array}$ \\
\hline 9 & 27 & $M$ & Cystic fibrosis & - & - & 0 & 0 & 2 & 7 & $\begin{array}{c}0.3 \\
(0.2-0.4)\end{array}$ \\
\hline 10 & 42 & $M$ & $\begin{array}{l}\text { Centrolobular } \\
\text { emphysema }\end{array}$ & - & - & 0 & 0 & 1 & 24 & $0.2(-)^{\prime}$ \\
\hline 11 & 24 & $\mathrm{~F}$ & Cystic fibrosis & - & - & 0 & 0 & 5 & 30 & $\begin{array}{c}0.2 \\
(0.2-1)\end{array}$ \\
\hline 12 & 23 & $M$ & Cystic fibrosis & - & - & 0 & 0 & 6 & 42 & $\begin{array}{c}0.2 \\
(0.2-0.2)\end{array}$ \\
\hline
\end{tabular}

* CMV status at time of transplantation: $\mathrm{D}$, donor; R, recipient; GVH, graft-versus-host. $\dagger$ Total number of CMV infection episodes in the patient during the follow-up; $\ddagger$ One sample was taken into account as BAL became CMV positive 8 days later; ${ }^{*}{ }^{* k}$ expressed as median (min-max)

\section{Lymphocyte immunotyping by flow cytometry}

Lymphocyte subsets in BAL and blood were evaluated by multiparameter analysis of leukocytes by flow cytometry using a Coulter Profile II cytometer (Coulter Cytometry Products; Coultronics France SA, Margency, France). Following gentle mixing, $100 \mu \mathrm{l}$ of each whole blood specimen or $0.5 \times 10^{6} \mathrm{BAL}$ cells were incubated with 10 $\mu \mathrm{l}$ of monoclonal antibody at room temperature for 15 min before lysis using the Coulter Q-Prep procedure. The following monoclonal antibodies - all conjugated with fluorescein isothiocyanate (FITC) or phycoerythrin (RD1) - (Coulter Cyto-Stat/Coulter clone; Coultronics France SA, Margency, France) were used: T11-RD1/B4FITC (anti human CD2/CD19), anti human CD3 (IgG1)FITC, T4-RD1/T8-FITC (anti human CD4/CD8), T8FITC/S6F1-RD1 (anti human CD8/CD11a), NKH-1-RD1 (anti human CD56), TiGammaA.1-FITC (anti human TiGammaA). The cells were analyzed on forward-angle light scatter and $90^{\circ}$ light scatter using a lymphocyte gate.

We focused our attention on surface adhesion molecules, particularly LFA-1, since the absence of cell surface LFA1 has been proposed as a mechanism of escape from immunosurveillance [16]. The S6F1 (CD11a) lymphocyte surface antigen reacts with the LFA-1 antigen and is expressed on approximately $10 \%$ of unfractionated $\mathrm{T}$ cells, $15 \%$ of CD4+ cells and 50\% of CD8+ cells. [17]. The S6F1 antibody can distinguish killer effector $(\mathrm{CD} 8+/ \mathrm{S} 6 \mathrm{~F} 1+)$ cells from the precursor of killer effector (CD8+/S6F1-) cells among CD8+ T lymphocytes [17]. NKH-1 (CD56) defining a natural killer cell antigen, is expressed on a 
subpopulation of peripheral blood large granular lymphocytes demonstrating natural killer activity [18]. Anti$\mathrm{NKH}-1$ was found to react with approximately $12 \%$ of circulating lymphocytes and more than $90 \%$ of circulating $\mathrm{NKH}-1+$ cells are large granular lymphocytes [18].

Anti human TiGammaA recognizes an antigenic determinant carried by a T Cell Receptor (TCR) $\gamma$ chain. This antibody delineates a unique subset accounting for approximately $3 \%$ of human circulating lymphocytes [19]. The TiGammaA epitope is expressed on approximately two-thirds of the circulating $\mathrm{CD}_{3}+\mathrm{TCR}-\alpha / \beta$-fraction [19].

As a sufficient recovery rate of cells from BAL and a lymphocyte percentage $>3-5 \%$ are required to allow reliable flow cytometry processing, immunotyping of alveolar lymphocytes could only be performed on 22 BAL samples (11 CMV+ samples and $11 \mathrm{CMV}$-samples).

\section{Statistical analysis}

Results are expressed as mean \pm SEM. Comparisons of quantitative data were performed using a Mann-Whitney $U$ test for unpaired data or a Wilcoxon's signed-rank test for paired data. A P value $<0.05$ was considered significant.

\section{Results \\ Study population}

Seventeen of the 48 blood and BAL samples were CMV positive by culture (referred to as CMV+ samples): 12 in BAL, 4 in blood and BAL, and 1 in blood only. However, this last sample was taken into account because BAL became CMV positive 8 days later. Thirty-one samples were negative in blood and BAL (referred to as CMVsamples). Four \pm 0.7 blood and BAL samples were obtained per patient (range 1 to 10) between 1 to 42 months of follow-up after transplantation; 6 months \pm 1 (range 1 to 15) for CMV+ samples versus 11 months \pm 2 (range 1 to 42) for $C M V$-samples $(P<0.05)$. Seven samples were taken during antiviral treatment (2 CMV+ samples and 5 CMV-samples). A statistical analysis was unable to show that antiviral treatment influences the cell counts. Four of the patients with CMV infection had characteristic cytomegalic inclusion-bearing cells on cytologic examination of BAL or histopathologic examination of transbronchial biopsy specimens, and were therefore considered to present CMV pneumonitis [15].

\section{Differential cell counts in BAL and blood samples}

Results of differential cell counts in BAL are reported in Table 2. An increased percentage of alveolar lymphocytes was observed in CMV + samples compared to CMV-samples $(14.8 \pm 3.4$ versus $5.3 \pm 0.6 \%, \mathrm{P}<0.001)$. For the 4 episodes of CMV pneumonia, the percentage of alveolar lymphocytes was $11 \pm 3 \%$, and number of alveolar lymphocytes was $40 \pm 9 \times 103 / \mathrm{mL}$. The blood WBC count was $6.68 \pm 0.7$ and $6.97 \pm 0.7 \times 109 / \mathrm{L}(\mathrm{NS})$, and the absolute lymphocyte count was $0.60 \pm 0.07$ and $0.59 \pm$ $0.08 \times 109 / \mathrm{L}(\mathrm{NS})$ in CMV+ and CMV-samples, respectively.

Table 2: Differential cell counts in BAL from CMV+ and CMV-episodes (mean \pm SEM).

\begin{tabular}{|c|c|c|c|}
\hline & $\mathrm{CMV}+$ & CMV- & $P$ value \\
\hline $\begin{array}{l}\text { Total cell count }\left(10^{3 /}\right. \\
\mathrm{ml})\end{array}$ & $422 \pm 64$ & $383 \pm 45$ & NS \\
\hline Lymphocytes (\%) & $14.8 \pm 3.4$ & $5.3 \pm 0.6$ & $<0.001$ \\
\hline $\begin{array}{l}\text { Alveolar macrophages } \\
\text { (\%) }\end{array}$ & $76.5 \pm 5.2$ & $87.9 \pm 2.6$ & 0.03 \\
\hline Neutrophils (\%) & $8.7 \pm 3.3$ & $6.6 \pm 2.6$ & NS \\
\hline Siderophages* (\%) & $37 \pm 8$ & $47 \pm 6$ & NS \\
\hline
\end{tabular}

*: Siderophages, characterized by deep green-blue staining after Perl's reaction, were expressed as the percentage of the total macrophage population. NS: non significant $(p>0.1)$

\section{Lymphocyte subset counts in blood and BAL}

As shown in Table 3, CMV+ blood samples had a significantly higher B lymphocyte count (CD19+ cells); while CMV-samples tended to have higher natural killer lymphocyte (CD56+ cells) and TiGammaA+ lymphocyte counts. No difference was observed for CD8+ or CD4+ lymphocytes, expressed as percentage or in absolute numbers. CD11a was expressed on approximately $50 \%$ of CD8+ T lymphocytes in CMV+ and CMV-samples. The absolute number of CD8 + T lymphocytes in BAL was significantly higher in CMV+ samples (Table 3). Twenty percent of CD8 + T lymphocytes expressed CD11a.

\section{CD4/CD8 and CD8/CD3 ratios in BAL versus blood}

$\mathrm{CMV}+$ samples had a lower CD4/CD8 ratio in BAL than in blood $(\mathrm{p}=0.008)$, and a higher $\mathrm{CD} 8 / \mathrm{CD} 3$ ratio in $\mathrm{BAL}$ than in blood $(\mathrm{p}=0.002)$. In contrast, no significant difference was found between BAL and blood for either $\mathrm{CD} 4 / \mathrm{CD} 8$ or $\mathrm{CD} 8 / \mathrm{CD} 3$ ratios in CMV-samples. Comparisons of $\mathrm{CD} 4 / \mathrm{CD} 8$ and $\mathrm{CD} 8 / \mathrm{CD} 3$ ratios in BAL and blood were not statistically different between $\mathrm{CMV}+$ and CMV-samples.

\section{Discussion}

In the present study, BAL and blood lymphocyte subpopulations from lung transplant recipients with or without CMV pulmonary infection, but without graft rejection or bacterial infection, were compared. Lymphocytes were increased in bronchoalveolar fluid from patients with CMV pulmonary infection, but surprisingly only minor 
Table 3: Lymphocyte counts and lymphocyte subsets counts in blood and BAL.

\begin{tabular}{|c|c|c|c|}
\hline & CMV+ samples * & CMV-samples * & $P$ value \\
\hline Lymphocytes in blood $\dagger\left(/ \mathrm{mm}^{3}\right)$ & $602 \pm 75$ & $590 \pm 80$ & NS \\
\hline CD2+ blood $\left(/ \mathrm{mm}^{3}\right)$ & $428 \pm 64[69 \pm 4 \%]$ & $480 \pm 73[77 \pm 3 \%]$ & NS \\
\hline CD3+ blood $\left(/ \mathrm{mm}^{3}\right)$ & $414 \pm 64[66 \pm 4 \%]$ & $42 I \pm 61[74 \pm 3 \%]$ & NS \\
\hline CD4+ blood $\left(/ \mathrm{mm}^{3}\right)$ & $192 \pm 39[30 \pm 3 \%]$ & $188 \pm 29[33 \pm 3 \%]$ & NS \\
\hline CD8+ blood $\left(/ \mathrm{mm}^{3}\right)$ & $210 \pm 32[35 \pm 3 \%]$ & $209 \pm 28[37 \pm 3 \%]$ & NS \\
\hline CDI9+ blood $\left(/ \mathrm{mm}^{3}\right)$ & $126 \pm 23[23 \pm 3 \%]$ & $74 \pm 13[16 \pm 3 \%]$ & 0.02 \\
\hline CD8/CDIla + blood $\left(/ \mathrm{mm}^{3}\right)$ & $134 \pm 26[60 \pm 5 \%]$ & $105 \pm 17[48 \pm 5 \%]$ & NS \\
\hline $\mathrm{NKH}-\mathrm{I}+$ blood $\left(/ \mathrm{mm}^{3}\right)$ & $3 \pm 0.8[0.6 \pm 0.15 \%]$ & $7.3 \pm 1.9[1.3 \pm 0.3 \%]$ & 0.1 \\
\hline TirAl + blood $\left(/ \mathrm{mm}^{3}\right)$ & $5.7 \pm 1.5[1.1 \pm 0.3 \%]$ & $25 \pm 8[3.4 \pm 0.7 \%]$ & 0.08 \\
\hline Lymphocytes in $\mathrm{BAL} \ddagger\left(\times 10^{3} / \mathrm{ml}\right)$ & $69.5 \pm 19$ & $27.4 \pm 3.9$ & 0.04 \\
\hline $\mathrm{CD} 2+\mathrm{BAL}\left(\times 10^{3} / \mathrm{ml}\right)$ & $64.3 \pm 19[90 \pm 3 \%]$ & $25.2 \pm 3.7[91 \pm 1 \%]$ & 0.1 \\
\hline $\mathrm{CD} 3+\mathrm{BAL}\left(\times 10^{3} / \mathrm{ml}\right)$ & $60.4 \pm 18[82 \pm 3 \%]$ & $22.1 \pm 4.2[81 \pm 3]$ & 0.1 \\
\hline $\mathrm{CD} 4+\mathrm{BAL}\left(\times 10^{3} / \mathrm{ml}\right)$ & $11.6 \pm 5.6[14 \pm 2 \%]$ & $4.2 \pm 0.8[18 \pm 4 \%]$ & NS \\
\hline $\mathrm{CD} 8+\mathrm{BAL}\left(\times 10^{3} / \mathrm{ml}\right)$ & $49.4 \pm 13.2[69 \pm 4 \%]$ & $17.6 \pm 3.9[60 \pm 7 \%]$ & 0.04 \\
\hline $\mathrm{CDI} 9+\mathrm{BAL}\left(\times 10^{3} / \mathrm{ml}\right)$ & $0.06 \pm 0.03[0.2 \pm 0.01]$ & $0.1 \pm 0.03[0.5 \pm 0.12]$ & NS \\
\hline $\mathrm{CD} 8 / \mathrm{CDI} \mathrm{la}+\mathrm{BAL}\left(\times 10^{3} / \mathrm{ml}\right)$ & $13 \pm 7[20 \pm 10 \%]$ & $2 \pm 0.5[18 \pm 10 \%]$ & NS \\
\hline $\mathrm{NKH}-\mathrm{I}+\mathrm{BAL}\left(\times 10^{3} / \mathrm{ml}\right)$ & $1 \pm 0.5[1.7 \pm 0.9 \%]$ & $0.3 \pm 0.01[1.3 \pm 0.4 \%]$ & NS \\
\hline Ti $\gamma \mathrm{Al}+\mathrm{BAL}\left(\times 10^{3} / \mathrm{ml}\right)$ & $0.9 \pm 0.4[1.2 \pm 0.3]$ & $1.2 \pm 0.7[4.4 \pm 3 \%]$ & NS \\
\hline
\end{tabular}

*: Respective percentages given in brackets $\dagger:$ Lymphocyte subset counts in blood were determined in $17 \mathrm{CMV}+$ samples and $3 \mathrm{I} C \mathrm{CMV}$-samples. $\ddagger$ : Lymphocyte subset counts in BAL were determined in only II CMV+ samples and II CMV-samples. NS: non significant $(p>0.1)$

changes were observed in the distribution of the various subpopulations. In contrast, blood B-lymphocytes were significantly increased during CMV infection.

A significant increase in alveolar lymphocytes, expressed either in absolute number or as a percentage, was observed in the BAL fluid sampled concurrently with CMV infection. Such an increase has already been reported in pulmonary CMV infection and during acute rejection $[5,12,13]$. The presence of lymphocytic alveolitis is therefore considered to be useless to differentiate rejection from CMV infection. An increase in pulmonary CD8+ T lymphocytes during CMV infection has previously been reported [13], and CD8+ cytotoxic lymphocyte counts were found to be increased during CMV pneumonia [10]. However, interestingly, we found that pulmonary CMV infection was associated with only minor modifications in the respective alveolar lymphocyte subpopulations limited to a slight increase in the CD8+T lymphocyte subpopulation. The change in the $\mathrm{CD} 4 / \mathrm{CD} 8$ ratio reflects an increase in the CD8 lymphocyte subset rather than a decrease in $\mathrm{T}$ helper lymphocytes [13]. As demonstrated by the differences in the CD4/CD8 and CD8/CD3 lymphocyte ratios in blood and BAL during CMV infection, the higher CD8+ T lymphocyte count in BAL is highly suggestive of local pulmonary recruitment.

The cellular changes observed in our studies suggest a slight increase in cell-mediated immune effectors in the lungs [2,3]. Pulmonary CMV infection primes the host immune system, either in a CMV-specific or non-specific fashion [20-23] and several arguments are in favor of a CMV-specific immune response of the recipient as it has been previously shown that CD8 + T lymphocytes play an important role in host defense against CMV infection [79]. Lymphocyte proliferation kinetic studies have also shown accumulation of primed CMV-specific lymphocytes within the lung allograft during CMV infection [22]. However, in the present study, no difference was observed in terms of the absolute number of activated cytotoxic $(\mathrm{CD} 8+/ \mathrm{CD} 11 \mathrm{a}+)$ lymphocytes. This could be a consequence of either pharmacological immunosuppression or CMV "per se" [24]. Alternatively, the cellular changes observed in the alveolar spaces may be related to a CMV-induced alloreaction which could provide a nonvirus-specific response [23]. It has been demonstrated that alveolar macrophages are activated during pulmonary CMV infection $[10,12]$ and secrete cytokines such as IL-6, IL-1, and TNF-?? which could therefore promote the recruitment and maturation of CD8+ cytotoxic lymphocytes [10]. Moreover, endothelial cells can be infected with CMV [25] and may be the target of alloreactive cytotoxic lymphocytes [26], which could subsequently migrate to alveolar spaces.

Gamma/delta T lymphocytes tend to be more numerous in the blood of patients without infection; however, their role and function during CMV infection are largely un- 
known. Recently, it has been demonstrated that gamma/ delta $\mathrm{T}$ cell expansion in kidney allograft recipients follows CMV infection and could possibly be an immunologic consequence of this infectious disorder [27].

Lastly, our finding of a poor inflammatory response to pulmonary CMV infection could be in agreement with the hypothesis that CMV pneumonia is not exclusively a consequence of an immunopathological process $[28,29]$. In the present study, the BAL samples collected in 4 patients during CMV pneumonia showed a particularly low percentage of alveolar lymphocytes.

In the present study, blood B lymphocytes were significantly increased during CMV infection. The effects of $\mathrm{CMV}$ infection on B-cell differentiation have not yet been extensively studied [30]. However, there is some evidence that CMV can directly activate B-cells in vitro $[31,32]$. This response to CMV infection seems to consist of polyclonal activation of B cells, as previously demonstrated [32] and confirmed by us after $\kappa / \lambda$ staining of these B-lymphocytes (J-F Bernaudin, personal results), which could probably be responsible for anti-CMV antibody secretion $[32,33]$. Interestingly, such an event was not observed in the alveolar space, in which B lymphocytes were almost entirely absent. As lymphocyte immunotyping by flow cytometry is rapid and easy, monitoring of variations in blood B-lymphocyte counts could therefore be indicative of CMV infection.

\section{Conclusion}

An increase in blood B-lymphocytes appears to be a clinical feature of pulmonary CMV infection. In contrast, pulmonary CMV infection is accompanied by only minor changes in BAL lymphocyte subpopulations. In our experience, evaluating the main subsets of alveolar lymphocytes therefore appears to be of limited clinical value in the diagnosis of pulmonary CMV infection.

\section{Competing interests \\ none declared}

\section{Acknowledgments}

This study was partly supported by a grant from the Contrat Recherche Clinique, AP-HP 913009 (Paris, France). François Stéphan was a fellow of the Fondation pour la Recherche Médicale

We are greatly indebted to Patrick Honderlick for virology studies.

\section{References}

I. Trulock EP: Lung transplantation. Am J Resp Crit Care Med 1997, I 55:789-8|8

2. Grundy JE, Shanley JD, Griffiths PD: Is cytomegalovirus interstitial pneumonitis in transplant recipients an immunopathological condition?. Lancet 1987, ii:996-999

3. Tanaka K, Koga Y, Lu YY, et al: Murine cytomegalovirus-associated pneumonitis in the lungs free of the virus. J. Clin. Invest 1994, 94:1019-1025
4. Escudier E, Fleury J, Cordonnier C, et al: Large granular lymphocytes in bronchoalveolar lavage fluids from immunocompromised patients with cytomegalovirus pneumonitis. Am J Clin Pathol 1986, 86:64I-645

5. Courtade M, Carré Ph, Martel S, et al: Données cytologiques du lavage alvéolaire chez le transplanté pulmonaire indemne de surinfection bronchique. Rev Mal Resp 1996, I 3:41 3-420

6. Shanley JD, Ballas ZK: Alteration of bronchoalveolar cells during murine cytomegalovirus interstitial pneumonitis. Am Rev Resp Dis 1985, |32:77-8|

7. Quinnan GV Jr, Kirmani N, Rook AH, et al: Cytotoxic T cellsin cytomegalovirus infection. HLA-restricted T-lymphocytes and non-T lymphocyte cytotoxic responses correlate with recovery from cytomegalovirus infection in bone-marrow-transplant recipients. $N$ Engl J Med I 982, 307:6-13

8. Rook AH, Quinnan GV Jr, Frederick WJR: Importance of cytotoxic lymphocytes during cytomegalovirus infection in renal transplant recipients. Am J Med 1984, 76:385-392

9. Riddell SR, Watanabe KS, Goodrich JM, et al: Restoration of viral immunity in immunodeficient humans by the adoptive transfer of T cell clones. Science 1992, 257:238-24I

10. Humbert M, Devergne O, Cerrina J, et al: Activation of macrophages and cytotoxic cells during cytomegalovirus pneumonia complicating lung transplantations. Am Rev Respir Dis 1992, 145: I I78-I I84

II. Clelland C, Higenbottam T, Stewart S, et al: Bronchoalveolar lavage and transbronchial biopsy during acute lung rejection and infection in heart-lung transplant patients. Studies of cell counts, lymphocyte phenotypes, and expression of HLA-DR and interleukin-2 receptor. Am Rev Respir Dis 1993, 147:13861392

12. Magnan A, Mege JL, Reynaud M, et al: Monitoring of alveolar macrophage production of tumor necrosis factor-alpha and interleukin-6 in lung transplant recipients. Am J Respir Crit Care Med 1994, 150:684-689

13. Whitehead BF, Stoehr C, Finkle C, et al: Analysis of bronchoalveolar lavage from human lung transplant recipients by flow cytometry. Resp Med 1995, 89:27-34

14. Paya CV, Wold AD, Smith TF: Detection of cytomegalovirus infections in specimens other than urine by shell vial assay and conventional tube cell cultures. J Clin Microbiol I 987, 25:755-757

15. Ljungman P, Griffiths P: Definitions of cytomegalovirus infections and disease. In: (Edited by Michelson S, Plotkin SA). Multidisciplinary approach to understanding of cytomegalovirus disease. Paris: Elsevier Science Publishers, 1993233-240

16. Clayberger C, Medeiros LJ, Link MP, et al: Absence of cell surface LFA-I as a mechanism of escape from immunosurveillance. Lancet 1987, 2:533-536

17. Morimoto C, Rudd CE, Letvin NL, et al: A novel epitope of the LFA-I antigen which can distinguish killer effector and suppressor cells in human CD8 cells. Nature 1987, 330:479-482

18. Hercend T, Griffin JD, Bensussan A, et al: Generation of monoclonal antibodies to a human natural killer clone. Characterization of two natural killer-associated antigens, NKH I A and NKH2, expressed on subsets of large granular lymphocytes. Clin. Invest 1985, 75:932-943

19. Triebel F, Faure F, Graziani M, et al: $\mathbf{A}$ unique $\mathbf{V}$-J-C -rearranged gene encodes a " protein expressed on the majority of CD3+ T cell receptor- $\gamma / \delta$ - circulating lymphocytes. J Exp Med 1988 167:694-699

20. Borysiewicz LK, Hickling JK, Graham S, et al: Human cytomegalovirus-specific cytotoxic $T$ cells. Relative frequency of stagespecific CTL recognizing the $72-k D$ immediate early protein and glycoprotein $B$ expressed by recombinant vaccinia viruses. J Exp Med 1988, 168:919-931

21. Riddell SR, Rabin M, Geballe AP, et al: Class I MHC-restricted cytotoxic T lymphocyte recognition of cells infected with human cytomegalovirus does not require endogenous viral gene expression. I Immunol I 991, | 46:2795-2804

22. Zeevi A, Uknis ME, Spichty KJ, et al: Proliferation of cytomegalovirus-primed lymphocytes in bronchoalveolar lavages from lung transplant patients. Transplantation 1992, 54:635-639

23. Keenan RJ, Lega ME, Dummer JS, et al: Cytomegalovirus serologic status and postoperative infection correlated with risk of developing chronic rejection after pulmonary transplantation. Transplantation 1991, 51:433-438 
24. Schrier RD, Rice GPA, Oldstone MBA: Suppression of natural killer cell activity and $T$ cell proliferation by fresh isolates of human cytomegalovirus. J Infect Dis 1986, 153:1084-1091

25. Grefte A, Van der Giessen M, Van Son W, et al: Circulatingcytomegalovirus (CMV)-infected endothelial cells in patients with an active CMV infection. J Infect Dis 1993, 167:270-277

26. Arbustini E, Morbini P, Grasso M, et al: Human cytomegalovirus early infection, acute rejection, and major histocompatibility class II expression in transplanted lung. Molecular, immunocytochemical, and histopathologic investigations. Transplantation 1996, 61:418-427

27. Déchanet J, Merville $P$, Bergé $F$, et al: Major expansion of $\mathbf{T}$ lymphocytes following cytomegalovirus infection in kidney allograft recipients. J Infect Dis 1999, 179: I-8

28. Morris DJ: Cytomegalovirus pneumonia-a consequence of immunosuppression and pre-existing lung damage rather than immunopathology?. Resp Med 1993, 87:345-349

29. Stals FS, Steinhoff G, Wagenaar SS, et al: Cytomegalovirusinduces interstitial lung disease in allogenic bone marrow transplant recipient rats independent of acute graft-versus-host response. Lab Invest 1996, 74:343-352

30. Rasmussen L: Immune response to human cytomegalovirus infection. Curr Top Microbiol Immunol I990, I54:22 I-249

31. Hutt-Fletcher LM, Balachandran N, Haswell Elkins M: B cell activation by cytomegalovirus. J Exp Med I 983, I 58:2 I7I-2 I76

32. Segondy M, Vendrell JP, Reynes ], et al: Cytomegalovirus-specific $B$ cell activation as a potential marker for the diagnosis of $c y-$ tomegalovirus infection. Eur J Clin Microbiol Infect Dis 1990, 9:745750

33. Jonjic S, Pavic I, Polic B, et al: Antibodies are not essential for the resolution of primary cytomegalovirus infection but limit dissemination of recurrent virus. J Exp Med 1994, 179:1713-1717

Publish with BioMed Central and every scientist can read your work free of charge

"BioMedcentral will be the most significant development for disseminating the results of biomedical research in our lifetime."

$$
\text { Paul Nurse, Director-General, Imperial Cancer Research Fund }
$$

Publish with BMC and your research papers will be:

- available free of charge to the entire biomedical community

- peer reviewed and published immediately upon acceptance

- cited in PubMed and archived on PubMed Central

- yours - you keep the copyright 